\title{
The Role of Diagnostic Biomarkers, Omics Strategies, and Single-Cell Sequencing for Nonalcoholic Fatty Liver Disease in Severely Obese Patients
}

\author{
Charlotte W. Wernberg ${ }^{1,2}$, Kim Ravnskjaer ${ }^{2,3}$, Mette M. Lauridsen ${ }^{1,2}$ (D) and Maja Thiele ${ }^{2,4,5, *(\mathbb{D})}$ \\ 1 Department of Gastroenterology and Hepatology, Hospital Southwest of Jutland, 6700 Esbjerg, Denmark; \\ Charlotte.Wilhelmina.Wernberg@rsyd.dk (C.W.W.); Mette.Enok.Munk.Lauridsen@rsyd.dk (M.M.L.) \\ 2 Center for Functional Genomics and Tissue Plasticity (ATLAS), University of Southern Denmark, \\ 5230 Odense, Denmark; ravnskjaer@bmb.sdu.dk \\ 3 Department of Biochemistry and Molecular Biology, University of Southern Denmark, \\ 5230 Odense, Denmark \\ 4 Center for Liver Research, Department of Hepatology and Gastroenterology, Odense University Hospital, \\ 5000 Odense, Denmark \\ 5 Institute for Clinical Research, University of Southern Denmark, 5230 Odense, Denmark \\ * Correspondence: Maja.thiele@rsyd.dk; Tel.: +45-2499-8068
}

\section{check for}

updates

Citation: Wernberg, C.W.; Ravnskjaer, K.; Lauridsen, M.M.; Thiele, M. The Role of Diagnostic Biomarkers, Omics Strategies, and Single-Cell Sequencing for

Nonalcoholic Fatty Liver Disease in Severely Obese Patients. J. Clin. Med. 2021, 10, 930. https://doi.org/ 10.3390/jcm10050930

Academic Editors: Lise Lotte Gluud and Nicolai Jacob Wewer Albrechtsen

Received: 10 January 2021

Accepted: 24 February 2021

Published: 1 March 2021

Publisher's Note: MDPI stays neutral with regard to jurisdictional claims in published maps and institutional affiliations.

Copyright: (c) 2021 by the authors. Licensee MDPI, Basel, Switzerland. This article is an open access article distributed under the terms and conditions of the Creative Commons Attribution (CC BY) license (https:// creativecommons.org/licenses/by/ $4.0 /)$.

\begin{abstract}
Liver disease due to metabolic dysfunction constitute a worldwide growing health issue Severe obesity is a particularly strong risk factor for non-alcoholic fatty liver disease, which affects up to $93 \%$ of these patients. Current diagnostic markers focus on the detection of advanced fibrosis as the major predictor of liver-related morbidity and mortality. The most accurate diagnostic tools use elastography to measure liver stiffness, with diagnostic accuracies similar in normal-weight and severely obese patients. The effectiveness of elastography tools are however hampered by limitations to equipment and measurement quality in patients with very large abdominal circumference and subcutaneous fat. Blood-based biomarkers are therefore attractive, but those available to date have only moderate diagnostic accuracy. Ongoing technological advances in omics technologies such as genomics, transcriptomics, and proteomics hold great promise for discovery of biomarkers and increased pathophysiological understanding of non-alcoholic liver disease and steatohepatitis. Very recent developments have allowed for single-cell sequencing and cell-type resolution of gene expression and function. In the near future, we will therefore likely see a multitude of breakthrough biomarkers, developed from a deepened understanding of the biological function of individual cell types in the healthy and injured liver.
\end{abstract}

Keywords: bariatric surgery; NAFLD; NASH; fatty liver; biomarkers; omics technologies

\section{Non-Alcoholic Fatty Liver Disease in Severely Obese Patients}

Obesity is a worldwide growing epidemic. A 2019 Lancet Commission declared obesity as one out of three epidemics that needs to be addressed due to their preeminent threat to human health [1]. Nearly one-quarter of U.S. citizens are predicted to be severely obese (body mass index, BMI, $>35 \mathrm{~kg} / \mathrm{m}^{2}$ ) by 2030, and it is estimated that the most frequent BMI-group among women in general will be 'severely obese' [2]. Non-alcoholic fatty liver disease (NAFLD) is a common manifestation of obesity, and the most common chronic liver disease worldwide, with a prevalence of $25 \%$ among adults [3]. NAFLD is a particular problem for severely obese patients, evidenced by observations in patients eligible for bariatric surgery. Up to $93 \%$ of these patients have NAFLD, one-fourth to two-thirds have non-alcoholic steatohepatitis (NASH), the progressive form of NAFLD, and 9-25\% have fibrosis, scarring of the liver, which ultimately may lead to cirrhosis (Table 1) [4,5]. 
Table 1. Histological staging and grading of non-alcoholic fatty liver disease ${ }^{1}$.

\begin{tabular}{|c|c|}
\hline Histological Characterisation & Description \\
\hline Steatosis & $\begin{array}{l}\text { When more than five percent of hepatocytes contain fat } \\
\text { vacuoles. Scored according to degree of fat infiltration: } \\
\text { S1: Minimal, } 5-33 \% \text { hepatocytes infiltrated by fat. } \\
\text { S2: Moderate, }>33-66 \% \text { hepatocytes infiltrated by fat. } \\
\text { S3: Severe, }>66 \% \text { hepatocytes infiltrated by fat. }\end{array}$ \\
\hline Non-alcoholic steatohepatitis & $\begin{array}{l}\text { Defined by presence of both steatosis, ballooning, and lobular } \\
\text { inflammation. Activity is scored according to severity: } \\
\text { Few ballooned hepatocytes versus prominent ballooning; and } \\
<2 \text { inflammatory foci per } 200 \text { Xfield, } 2-4 \text { foci, or }>4 \text { foci. }\end{array}$ \\
\hline Fibrosis & $\begin{array}{l}\text { In NAFLD, fibrosis begins by pericellular deposition of fibrillar } \\
\text { collagen fibers; gradually expanding to form large fibrotic } \\
\text { septae. Fibrosis is staged according to distribution and } \\
\text { magnitude: } \\
\text { F1: Mild, perisinusoidal or periportal fibrosis. } \\
\text { F2: Moderate, perisinusoidal and portal/periportal. } \\
\text { F3: Severe, bridging fibrosis. } \\
\text { F4: Cirrhosis, characterised by regeneration nodules. }\end{array}$ \\
\hline
\end{tabular}

\footnotetext{
${ }^{1}$ : Described according to the most commonly used histology score for grading and staging of NAFLD, the NAS-CRN system and the Kleiner fibrosis score (Nonalcoholic Steatohepatitis Clinical Research Network) [6].
}

We do not have a complete overview of the molecular mechanisms that drive NAFLD towards NASH and liver fibrosis, but believe that NASH marks a high risk of fibrosis formation, when the inflammatory activity leads to hepatic stellate cell activation, with subsequent deposition of fibrillar collagens in the extracellular matrix [7]. However, fibrosis progression in NAFLD is asymptomatic and takes place over several decades, with an estimated one-third of NAFLD patients exhibiting fibrosis progression, and progression rates of 14 years per one fibrosis stage for patients with simple steatosis, versus 7 years for patients with NASH [8]. This demonstrates that NAFLD is a complex trait, where the interindividual variation in disease phenotype likely arises from an interplay between genetic predisposition, environmental factors, and components of the metabolic syndrome $[9,10]$. For this reason, we still lack valid non-invasive alternatives to a liver biopsy. Fortunately, emerging technologies have made it possible to explore the complex biological systems in the liver during chronic liver injury [11,12]. Consequently, we are rapidly deepening our understanding of the pathways that drive NASH and liver fibrosis, while revealing new biomarkers and drug targets.

This review focuses on NAFLD in severely obese patients. We consider three main topics: Current state-of-the-art diagnostic tools, upcoming biomarkers in the form of new omics technologies, and finally, a probable new era in our understanding of liver disease aided by cutting edge technologies such as single cell sequencing.

\section{Existing Diagnostic Tools for NAFLD in Severely Obese Patients}

The diagnosis of liver fibrosis is central to risk stratification and management of NAFLD in severely obese patients, with advanced fibrosis $(\geq F 3)$ being the major prognostic predictor [13]. Underdiagnosis of advanced fibrosis may lead to delayed treatment, with excess liver-related morbidity and mortality; while overdiagnosis causes futile investigations and patient concern [14,15]. The association between NASH and fibrosis progression makes it highly desirable to also identify NASH non-invasively. However, there are no currently well validated tools for NASH diagnosis, which today can only be diagnosed by a liver biopsy. Steatosis is not of prognostic value, but diagnosis and monitoring of steatosis may be valuable for evaluating the efficacy of interventions [16].

Liver biopsy remains the gold standard to stage fibrosis, grade hepatic inflammatory activity, and score steatosis. Liver biopsy is however prone to complications, sampling error, and observer-variance. In severely obese patients, liver biopsy is particularly problematic, 
because it may be difficult to obtain sufficient material with a standard percutaneous approach due to a large subcutaneous fat layer. Therefore, non-invasive diagnostic tests are highly needed, to replace liver biopsy as the regulatory surrogate endpoint in treatment trials [17].

Current non-invasive diagnostic tests can be divided into imaging, elastography, and blood-based markers (Table 2).

Table 2. Advantages and disadvantages of diagnostic markers for the assessment of steatosis and advanced fibrosis in severely obese patient with non-alcoholic fatty liver disease (NAFLD).

\begin{tabular}{|c|c|c|c|c|}
\hline & \multicolumn{2}{|c|}{ Fibrosis } & \multicolumn{2}{|c|}{ Steatosis } \\
\hline & Advantages & Disadvantages & Advantages & Disadvantages \\
\hline \multicolumn{5}{|l|}{ Imaging } \\
\hline Ultrasound & $\begin{array}{l}\text { Low cost, widely } \\
\text { available in primary } \\
\text { and secondary care }\end{array}$ & $\begin{array}{l}\text { Poor quality in severely } \\
\text { obese patients. Only } \\
\text { accurate in case of } \\
\text { late-stage cirrhosis }\end{array}$ & $\begin{array}{l}\text { Low cost, widely } \\
\text { available in primary } \\
\text { and secondary care }\end{array}$ & $\begin{array}{l}\text { Poor quality in severely } \\
\text { obese patients. Only } \\
\text { accurate if }>20 \% \\
\text { fat-infiltrated } \\
\text { hepatocytes }\end{array}$ \\
\hline $\mathrm{CT}$ & $\begin{array}{l}\text { Widely available in } \\
\text { hospital care }\end{array}$ & $\begin{array}{l}\text { Radiation. Only } \\
\text { accurate in case of } \\
\text { cirrhosis }\end{array}$ & $\begin{array}{l}\text { Widely available in } \\
\text { hospital care }\end{array}$ & $\begin{array}{l}\text { Radiation. Only } \\
\text { accurate if }>20 \% \\
\text { fat-infiltrated } \\
\text { hepatocytes }\end{array}$ \\
\hline MRI & $\begin{array}{l}\text { No radiation in } \\
\text { contrast to } \mathrm{CT}\end{array}$ & $\begin{array}{l}\text { Low availability. Only } \\
\text { accurate in case of } \\
\text { cirrhosis }\end{array}$ & $\begin{array}{l}\text { MRI-PDFF is the most } \\
\text { accurate non-invasive } \\
\text { marker of steatosis } \\
\text { with AUROC's > } 0.90\end{array}$ & $\begin{array}{l}\text { Low availability. } \\
\text { Severely obese patients } \\
\text { may need special } \\
\text { scanner }\end{array}$ \\
\hline \multicolumn{5}{|l|}{ Elastography } \\
\hline $\mathrm{TE}$ & $\begin{array}{l}\text { Available in most } \\
\text { hepatology clinics. The } \\
\text { XL probe is developed } \\
\text { for obese patients }\end{array}$ & $\begin{array}{l}\text { Moderate accuracy } \\
\text { with AUROC's } \\
0.80-0.85\end{array}$ & $\begin{array}{l}\text { Controlled attenuation } \\
\text { paramenter, a } \\
\text { non-invasive steatosis } \\
\text { measure, is available } \\
\text { together with TE }\end{array}$ & $\begin{array}{l}\text { Poor diagnostic } \\
\text { accuracies with } \\
\text { AUROC's }<0.80\end{array}$ \\
\hline pSWE & $\begin{array}{l}\text { Available as } \\
\text { complementary } \\
\text { software on many } \\
\text { ultrasound equipment }\end{array}$ & $\begin{array}{l}\text { High risk of unreliable } \\
\text { measures in severely } \\
\text { obese patients }\end{array}$ & - & - \\
\hline 2D-SWE & $\begin{array}{l}\text { Measures liver stiffness } \\
\text { in a larger region of } \\
\text { interest than pSWE and } \\
\text { TE }\end{array}$ & $\begin{array}{l}\text { High failure rate in } \\
\text { severely obese patients }\end{array}$ & - & - \\
\hline MRE & $\begin{array}{l}\text { Most accurate } \\
\text { non-invasive marker of } \\
\text { fibrosis, with } \\
\text { AUROC's > }>.90\end{array}$ & $\begin{array}{l}\text { Low availability. } \\
\text { Severely obese patients } \\
\text { may need special } \\
\text { scanner }\end{array}$ & - & - \\
\hline \multicolumn{5}{|l|}{ Blood based } \\
\hline ELF & $\begin{array}{l}\text { Can be sampled in } \\
\text { primary care }\end{array}$ & $\begin{array}{l}\text { Patented test. Moderate } \\
\text { accuracy with } \\
\text { AUROC's } 0.80-0.85\end{array}$ & - & - \\
\hline FIB-4, APRI and NFS & $\begin{array}{l}\text { Can be measured from } \\
\text { routine liver blood tests }\end{array}$ & $\begin{array}{l}\text { Insufficient diagnostic } \\
\text { accuracy with } \\
\text { AUROC's }<0.80\end{array}$ & - & - \\
\hline
\end{tabular}

Abbreviations and explanation. 2D-SWE: Two-dimensional shear-wave elastography, an ultrasound-based technique. AUROC: Area under the receiver operating characteristics curve. CT: Computer tomography. ELF: Enhanced liver fibrosis test, an algorithm of hyaluronic acid, propeptide of type III collagen, and tissue inhibitor of metalloproteinase-1. FIB-4: Fibrosis- 4 test, an algorithm of age, aspartate transaminase, alanine transaminase, and platelet count. NFS: NAFLD Fibrosis Score, an algorithm of age, body mass index, presence of diabetes, aspartate transaminase, alanine transaminase, platelet count, and albumin. MRE: Magnetic resonance elastography. MRI: Magnetic resonance imaging; PDFF: Proton density fat fraction. pSWE: Point shear-wave elastography, an ultrasound-based technique. TE:

Vibration controlled transient elastography, an ultrasound-based technique. 


\subsection{MR-Based Techniques}

Magnetic resonance elastography (MRE) is the most accurate non-invasive fibrosis marker in NAFLD, with areas under the receiver operating characteristics curve (AUROCs) above 0.90 for both significant $(\geq F 2)$ and advanced fibrosis $(\geq F 3)$ [18]. During MRE, an acoustic driver placed on the patient's abdominal right upper quadrant induces shear waves in the liver. The velocity of these waves can be converted to an elastogram, measuring liver stiffness [19]. MRE is not influenced by a large subcutaneous layer, and the method retains an AUROC exceeding 0.90 in severely obese patients [20]. However, most MR equipment has weight restrictions (140-180 kg/300-400 Ibs) and the diameter of the scanner, need for physical breath holding, and psychological challenges of cramp spaces can be a hindrance for morbidly obese patients. Another obvious limitation of MRE is restricted availability, reserved for tertiary centers and research settings. As all elastography techniques, MRE is also limited by false positives in case of hepatic inflammation, congestion, or obstructive cholestasis. Finally, diagnostic cut-offs may vary due to spectrum bias in various studies, and differences in the hardware and software used.

Magnetic resonance imaging proton density fat fraction (PDFF) is highly accurate for non-invasive assessment of hepatic steatosis, also in obese patients (AUROCs $>0.95$ ) $[21,22]$. However, most diagnostic studies report mean BMI's around $35 \mathrm{~kg} / \mathrm{m}^{2}$ and only investigate per protocol diagnostic accuracies, discounting failed measurements. In contrast, a study specifically in patients undergoing bariatric surgery with a mean BMI of $45 \mathrm{~kg} / \mathrm{m}^{2}$ reported failed measurements in more than one-third of patients with resulting poor accuracies in intention-to-diagnose analyses [23].

\subsection{Ultrasound and Computer Tomography}

Neither ultrasonography or computed tomography can be used to stage fibrosis [24]. Both modalities can detect cirrhosis in case of definite, radiological signs such as lobulized liver surface, irregular parenchymal structure and signs of portal hypertension, but ultrasonography will often be the preferred first-line imaging modality, because it is radiation-free and have Doppler.

Ultrasound also remains the most common way of diagnosing moderate and severe hepatic steatosis; it is accessible, safe, low cost, and has a good accuracy for detecting steatosis if $\geq 20 \%$ of hepatocytes contain fat vacuoles [25]. However, ultrasound has limited quality in patients with high BMI, leading to poor sensitivities and specificities in NAFLD cohorts of bariatric surgery patients, between $49-65 \%$ and $75-90 \%$, respectively [26,27].

\subsection{Ultrasound Elastography and Controlled Attenuation Parameter}

Ultrasound elastography can be either vibration-controlled transient elastography (TE) with the equipment FibroScan (Echosens, Paris, France), point shear-wave elastography (pSWE), or 2-dimensional shear-wave elastography (2D-SWE) [28]. All techniques estimate liver stiffness by measuring the velocity of shear-waves induced in the liver by either a mechanical push-pulse (TE) or by the ultrasound beam (pSWE, 2D-SWE). The diagnostic accuracies for fibrosis in NAFLD patients are almost similar across the three techniques, with pSWE having slightly lower AUROCs than TE or 2D-SWE (AUROCs just above 0.80 for significant fibrosis, and above 0.85 for advanced fibrosis) [29]. However, reported diagnostic accuracies may be falsely high in the population of NAFLD patients because the quality and success rate of ultrasound elastography is hampered by a thick subcutaneous layer, and most studies report per-protocol, not intention-to-diagnose analyses [29]. The Fibroscan equipment has partially solved the problem of failed measurements by introducing the XL-probe for TE in patients with BMI $>30 \mathrm{~kg} / \mathrm{m}^{2}$ or a skin-capsule distance exceeding $25 \mathrm{~mm}$. Liver stiffness measurements with XL probe is approximately $20 \%$ lower than with the $\mathrm{M}$ probe in direct comparisons, but when using the $\mathrm{M}$ and $\mathrm{XL}$ probes as recommended, liver stiffness measures are comparable across fibrosis stages [30,31]. Consequently, the same diagnostic cut-offs can be used with both probes. A highly accurate cut-off to rule 
out advanced fibrosis in NAFLD is $8 \mathrm{kPa}$, while $12-15 \mathrm{kPa}$ rules in advanced fibrosis with good accuracy, if causes of false positive measurements can be excluded [19,32].

Controlled attenuation parameter (CAP) is a tool for diagnosing steatosis only available with FibroScan. However, a recent individual-patient data meta-analysis found poor diagnostic accuracies for CAP to detect steatosis, with AUROCs well below 0.80 [33]. In the subpopulation of bariatric surgery patients, diagnostic accuracies were marginally better, but remained $<0.80$, with sensitivities and specificities below $80 \%$ and wide confidence intervals for the optimal cut-off points.

\subsection{Blood-Based Markers}

Diagnostic serum markers have an applicability advantage over imaging-based methods, in that it is almost always feasible to sample blood. The enhanced liver fibrosis test (ELF, Siemens Healthcare, Erlangen, Germany) is the most extensively investigated of the commercial serum markers [34]. ELF appears to have a slightly higher AUROC, than other commercial markers, but a direct comparison with FibroMeter ${ }^{\mathrm{V} 2 \mathrm{G}}$ did not show a difference in diagnostic accuracy [35]. ELF has slightly lower diagnostic accuracies (AUROC of 0.83 for advanced fibrosis) than TE when comparing studies using per-protocol analyses, while a diagnostic study in alcohol-related liver disease found comparable diagnostic accuracies of ELF versus elastography techniques in intention-to-diagnose analyses [36]. ELF seem to be equally accurate in patients with severe obesity, though existing studies are scarce and underpowered $[37,38]$. Other available commercial biomarkers like FibroMeter ${ }^{2 \mathrm{G}}$, FibroTest/Fibrosure, Hepascore, and ProC3 may be good alternatives to ELF [39,40].

Non-patented biomarkers are algorithms from routine liver blood tests and clinical parameters [39]. They may be useful as first line testing for screening strategies, but has insufficient accuracy as diagnostic tools for significant and advanced fibrosis [41]. Similarly, a number of algorithms for steatosis assessment have been developed, utilizing biochemistry and clinical variables, but none of them perform with adequate diagnostic accuracy [19].

Since none of the available blood-based biomarkers are highly accurate, there is still an unmet need for biomarkers to diagnose advanced fibrosis. Current efforts focus on combining biomarkers, either in parallel or sequential [19]. Further, we need biomarkers to detect NASH, prognosticate, and to assess efficacy of interventions. For the latter, several candidate biomarkers are under evaluation [42,43]. Patients listed for bariatric surgery also constitute a particularly interesting cohort for evaluation of novel biomarkers, due to the easy access to peroperative liver tissue, and their massive, sustained weight loss post-surgery [44].

\section{Omics Technologies as Upcoming Biomarkers}

'Omics' refer to global disciplines in biological research such as genomics, transcriptomics, proteomics, or metabolomics. The goal of omics is to extract patterns and biological meaning from large-scale, high-dimensional data [45]. Today, several omics disciplines are well-established. In this section, we will discuss three omics disciplines that have already contributed significantly to our understanding of NAFLD (Figure 1). 


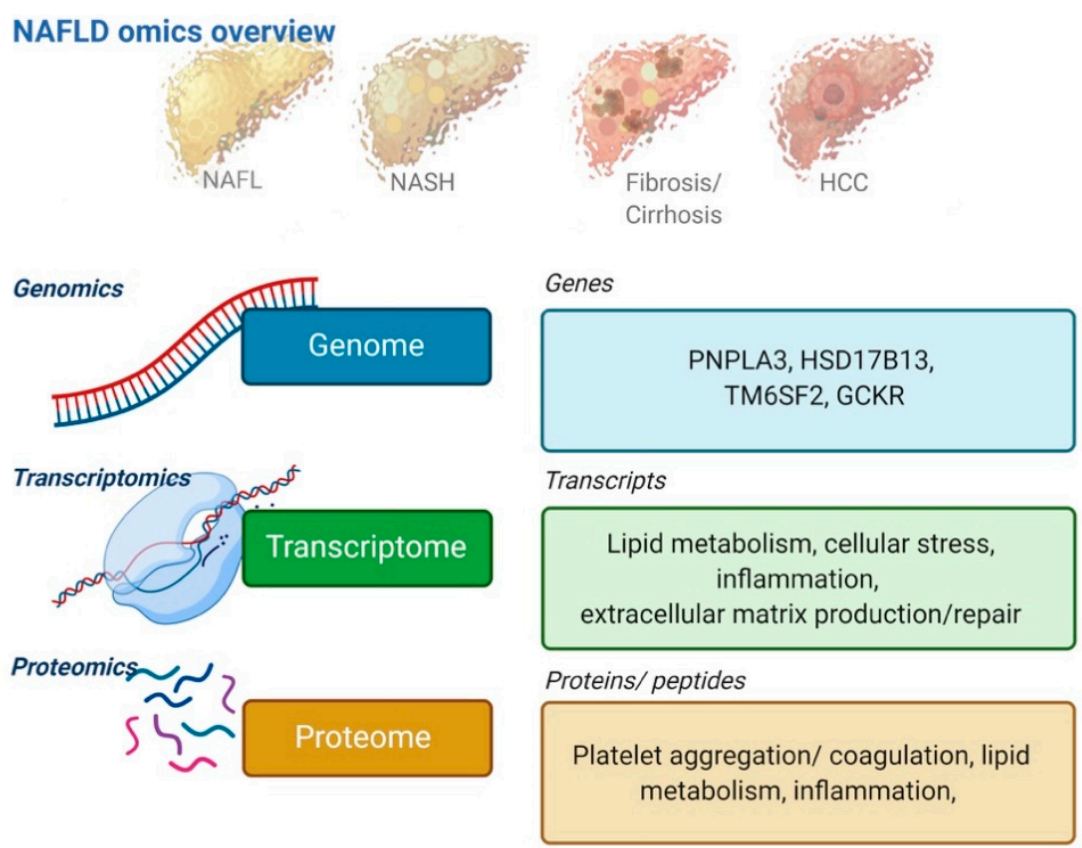

Figure 1. Omics technologies which may mature into implementable biomarkers in the near future; with examples of signals from genomics, transcriptomics, and proteomics that have been associated with NAFLD disease severity.

\subsection{Genomics}

The disposition for NAFLD has been excessively investigated in genome-wide association studies (GWAS), whereby hundreds of thousands of single nucleotide polymorphisms (SNPs) are paired with information on liver diagnoses, liver enzymes, or other measurable traits $[10,46,47]$. Since GWAS study associations, they may inform NAFLD patient risk assessment and stratification, whereas use of genetic information for NAFLD treatment or pathophysiological understanding will require further functional analyses. Moving beyond simple associations, current challenges are the multifactorial nature of NAFLD pathogenesis, limited linkage between the traits investigated, and the causative SNPs, as well as the incomplete characterization of the $98.8 \%$ non-coding part of the human genome [48].

The strongest genetic risk factor for NAFLD is found in the PNPLA3 (patatin-like phospholipase domain-containing protein 3) gene. The PNPLA3 rs738409[G] allele (causing an I148M substitution) associates with both steatosis, NASH, cirrhosis, and hepatocellular carcinoma, and predicts an earlier age at NAFLD diagnosis [46,49-51]. Homozygous carriers of PNPLA3 rs738409[G] have a three-fold risk of steatohepatitis, and a four-fold risk of cirrhosis relative to non-carriers. Its association is most pronounced in Hispanics, indicating interactions with other genomic loci, and more than $20 \%$ of the population carries the risk allele, so the collective effect of PNPLA3 on NAFLD is high [51].

To date, further $>10$ genetic variants have been associated with NAFLD [46,52]. The best validated are TM6SF2 (transmembrane 6 superfamily member 2), which may be required for normal VLDL secretion, while GCKR (glucokinase-regulator) regulates hepatocyte glucose metabolism. Impaired TM6SF2 and GCKR function associates with fibrosis and NAFLD, but not NASH [46]. HSD17B13 [TA] (hydroxysteroid 17-beta dehydrogenase 13) encodes a hepatic lipid droplet protein and is associated with a protective effect against cirrhosis in fatty liver diseases due to NAFLD or alcohol [53].

Adiposity amplifies the effects of the PNPLA3 allele along the entire spectrum of NAFLD severity [10], but it is unknown whether severe adiposity amplifies or attenuates the effect of the other SNPs. In subjects eligible for bariatric surgery, PNPLA3 and GCKR were associated with steatosis and fibrosis $[54,55]$. However, both studies included patients 
without advanced fibrosis, and used surgical biopsies, which are obtained preoperatively after weight loss, when steatosis has regressed.

From a biomarker perspective, attempts have been made to incorporate the validated genetic risk alleles in genetic risk scores, for use as risk stratification tools [56]. So far, none have passed to clinical implementation, and their cost-benefit, utility, and context of use as required by regulators are still up for debate. However, with diminishing costs for targeted SNP sequencing, we expect that genetics may be an integrated part of patient management in few years.

\subsection{Transcriptomics}

Transcriptomics is the quantitative assessment of all RNA, coding as well as noncoding, and it offer insights into differential gene expression and gene regulatory mechanisms in a cell population or tissue. Bulk liver transcriptomics were the first to investigate NAFLD, and are still the most common, but are disproportionately dominated by the parenchymal hepatocytes, which make up $60-70 \%$ of the cells in the healthy liver (Figure 2). Bulk transcriptomics therefore has limited value for the analysis of less abundant cell types [57].

\section{Major cell types of the human liver}

\begin{tabular}{|c|c|c|c|c|c|c|}
\hline & $\begin{array}{l}\text { Hepatocytes } \\
\text { (Epithelial) } \\
\text { Parenchymal }\end{array}$ & $\begin{array}{c}\text { Intrahepatic } \\
\text { cholangiocytes } \\
\text { (CHCs; epithelial) }\end{array}$ & $\begin{array}{c}\text { Liver } \\
\text { endothelial } \\
\text { cells (LECs) }\end{array}$ & $\begin{array}{l}\text { Hepatic stellate } \\
\text { cells (HSCs) } \\
\text { Nonparenchymal }\end{array}$ & $\begin{array}{l}\text { Kupffer cells } \\
\text { (KCs) }\end{array}$ & Other cells \\
\hline Cell type & Steatotic & & & & & \\
\hline $\begin{array}{l}\text { Biological } \\
\text { insights } \\
\text { from } \\
\text { scRNAseq }\end{array}$ & $\begin{array}{l}\text { Functional zonation } \\
\text { Periportal: Oxidation and } \\
\text { fatty acid metabolism } \\
\text { Mid-zonal: CYP-450 } \\
\text { xenobiotic metabolism. } \\
\text { Other functions: Plasma } \\
\text { protein synthesis, } \\
\text { detoxification, bile } \\
\text { production and } \\
\text { carbohydrate/lipid } \\
\text { metabolism. }\end{array}$ & $\begin{array}{l}\text { Express cell } \\
\text { adhesion molecule } \\
\left(\text { EpCAM }^{+}\right) \text {and may } \\
\text { be divided into } \\
\text { mature } \mathrm{CHCs,} \\
\text { hepatocyte-biased } \\
\text { and KRT19+ naive } \\
\text { progenitors. }\end{array}$ & $\begin{array}{l}\text { Fenestrated sinusoial } \\
\text { LECs; major functions } \\
\text { in scavenging, vascular } \\
\text { exchange and } \\
\text { immunoregulation. } \\
\text { Significant zonation, } \\
>60 \% \text { of genes zonated } \\
\text { along the porto-central } \\
\text { axis. }\end{array}$ & $\begin{array}{l}\text { Sinusoidal pericytes } \\
\text { involved in sinusoidal } \\
\text { integrity and exchange. } \\
\text { Major precursor of } \\
\text { NASH-associated } \\
\text { PDGFRA myofibro- } \\
\text { blasts located in the } \\
\text { fibrotic niche. } \\
\text { Quiescent HSCs may } \\
\text { regulate sinusoidal } \\
\text { blood flow. }\end{array}$ & $\begin{array}{l}\text { Defined KCs as } \\
\text { CD163+MARCO+ } \\
\text { CD5L+TIMD4* } \\
\text { macrophages } \\
\text { involved in } \\
\text { scavenging and } \\
\text { surveliance. Lost } \\
\text { in murine NASH. } \\
\text { Human and } \\
\text { murine KCs show } \\
\text { conserved tran- } \\
\text { scriptomic profile. }\end{array}$ & $\begin{array}{l}\text { Scar-associated } \\
\text { macrophages }(\mathrm{SAMs} \text {; } \\
\text { TREM2* } \mathrm{CD}^{*} \mathrm{MNDA}^{*} \text { ) in } \\
\text { fibrotic liver - localized } \\
\text { to areas of scarring. } \\
\text { Also seen in murine } \\
\text { NASH. } \\
\text { Intrahepatic T-cells, } \\
\text { distinct from circulating. } \\
\text { Expansion of SELL } \\
\text { CCR7 }{ }^{+} \text {CD4 } \\
\text { lin cirrhotic } \\
\text { livers. }\end{array}$ \\
\hline $\begin{array}{l}\text { Short } \\
\text { description }\end{array}$ & $\begin{array}{l}\text { Hepatic parenchyma: } \\
90 \% \text { of liver volume }\end{array}$ & $\begin{array}{l}\text { Epithelial biliary } \\
\text { tree cells }\end{array}$ & $\begin{array}{l}\text { Line sinusoids and } \\
\text { larger blood vessels }\end{array}$ & $\begin{array}{l}\text { Pericyte and } \\
\text { fibrogenic precursor }\end{array}$ & $\begin{array}{l}\text { Liver resident } \\
\text { macrophages }\end{array}$ & Rare in healthy liver \\
\hline
\end{tabular}

Figure 2. Major cell types of the human liver. Single-cell and cell type-resolved omics studies have all added to our understanding of liver biology in health and disease.

Bulk transcriptomics studies in human NAFLD and steatohepatitis have described changes to genes involved in lipid handling, inflammation, cell migration, extracellular matrix turnover, and regenerative processes $[58,59]$. Genes linked to core hepatocyte functions - the metabolism of lipids, glucose, amino acid, and xenobiotics-appear downregulated [59-61], while up-regulated genes in severe NAFLD are associated with tissue remodeling, progenitor cells, cancer, and cardiovascular disease [58]. A recent study of 620 severely obese patients compared transcriptomes of biopsy-validated simple steatosis versus NASH, and revealed distinct gene sets indicative of sexual dimorphism, implicating that novel NASH drug targets could be gender dependent [62]. Immune activation can also be observed on a transcriptional level: A study in severely obese patients with 
NASH and/or significant fibrosis found interleukin 32 to be the most heavily upregulated transcript, and circulating interleukin 32 levels corresponded to the expression in the liver tissue [63]. This finding was replicated in a recent multicenter study of 206 NAFLD patients, together with an additional 24 gene signatures, most of whom could be translated to circulating protein levels [61]. These findings underline the particular strength of transcriptomics, linking changes in gene expression to serum markers.

\subsection{Proteomics}

The proteome reflects immediate cellular processes, and therefore holds obvious potential for biomarker and drug-target discovery. Mass spectroscopy-based proteomics now makes it possible to identify and quantify thousands of proteins from liver tissue and the circulation [64]. This is in contrast to prior biomarker-finding studies, which targeted a limited number of specific proteins [34].

The first proteomics study in NAFLD determined hepatic protein abundance in liver samples from obese subjects in four groups: Obese without NAFLD, simple steatosis, and NASH with or without fibrosis [65]. They identified nine proteins that were differentially expressed across the four groups, many with probable pathophysiological functions: Hepatic lipid content, inflammation, and fibrosis. Lumican was one of the overexpressed proteins in NASH, an extracellular matrix proteoglycan that regulates collagen fibrilformation. Another case-control study even found elevated serum levels of lumican in NASH [66]. They found additional differences in 55 circulating proteins between simple steatosis and NASH, and differences in 15 proteins between NASH without versus with advanced fibrosis. Proteins involved in platelet aggregation and coagulation were elevated in NAFLD and NASH patients, while fibrinogens were significantly reduced. Finally, a case control study of the plasma proteome described nine candidate biomarker proteins, of which polymeric immunoglobulin receptor increased in persons with NAFLD, and further with cirrhosis. [67]. This highlights the potential for proteome analysis to discover new biomarkers in liver disease.

Another highly promising omics field is metabolomics, including circulating, urine or stool lipids, and metabolites [68-70]. This field is particularly interesting due to the causal role of metabolic dysfunction for the progression liver fibrosis in NAFLD patients. As a consequence, diagnostic molecules may also yield pathophysiological understanding and be druggable targets [71]. However, both the proteomics and metabolomics fields need to validate candidate biomarkers in biopsy-verified, diagnostic test cohorts that represent the full spectrum of disease in consecutively recruited NAFLD patients.

\section{Single-Cell and Cell Type-Resolved Omics Approaches to NAFLD}

The liver tissue has a complex lobular architecture and is composed of multiple cell types that interact with one another and communicate with surrounding tissues (Figures 2 and 3). 


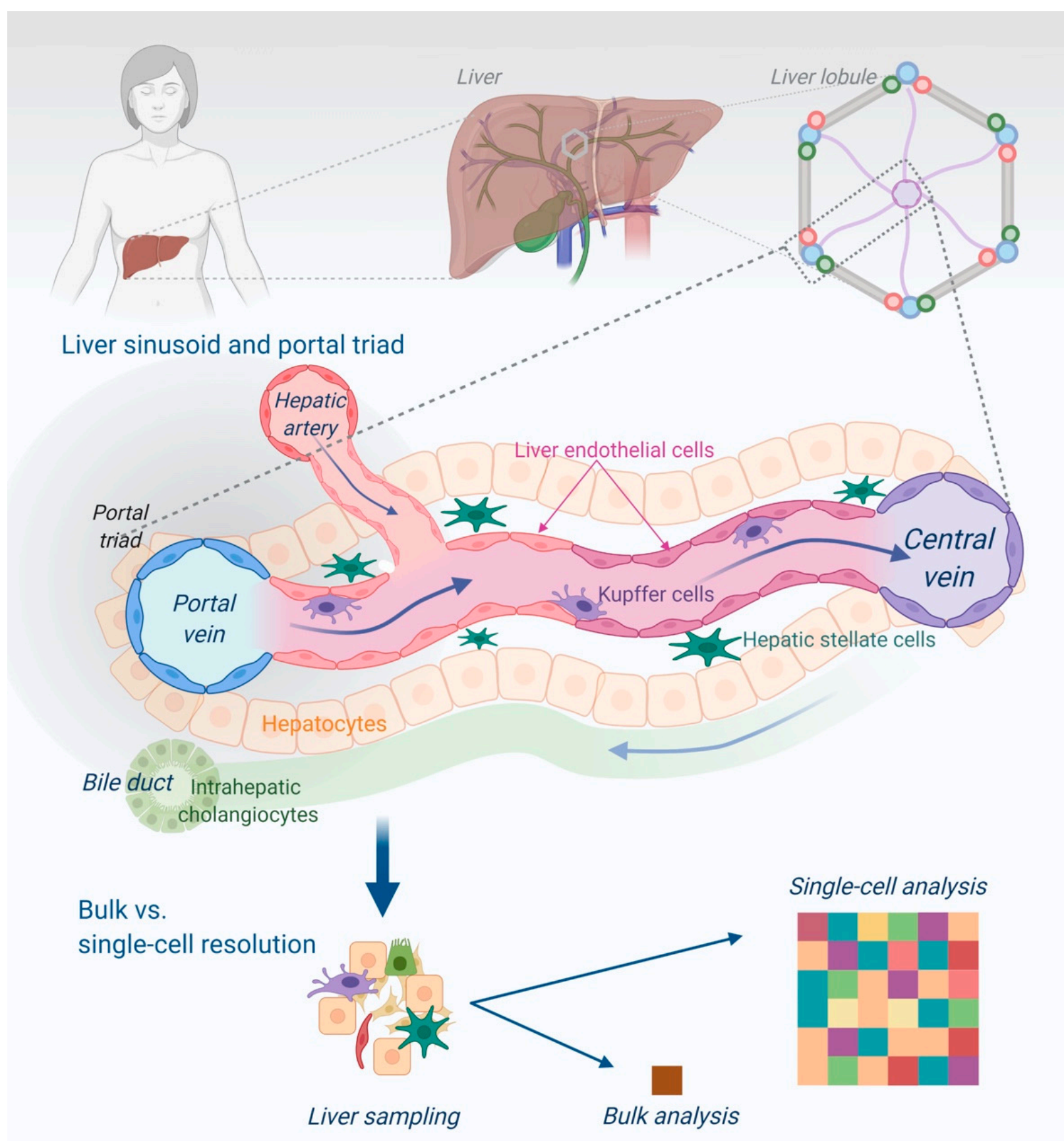

Figure 3. The structure of a liver lobule, its zonation and different cell types highlights the advantage of single-cell analysis. Healthy hepatic lobules are zonated from the portal triads (portal vein, hepatic artery, and bile duct) towards the central vein. Oxygenated, arterial blood and nutrient-rich portal venous blood enters the lobule from the portal triad, and is transported back to the circulation via a central vein.

By enabling the characterization of individual cell types during NAFLD progression, single-cell approaches have already offered novel insights into hepatocellular dynamics that could not be obtained from conventional bulk assays [61,72]. The techniques are still reserved for basic science, with few translational studies, but further technological developments and cost-reductions will likely spread the use of single-cell and cell typeresolved omics approaches, for deepened understanding of the cellular processes during NAFLD progression and regression, and eventual biomarker development. 


\subsection{Single-Cell Transcriptomics}

Single-cell RNA sequencing and single-nucleus RNA sequencing allowed scientists to characterize transcriptomes of individual cells in human and rodent liver, to establish a cell-atlas of the human liver, and to understand the functions and crosstalk of hepatic cell types [73]. Though most evidence is from murine models, and study normal liver, liver cancer, or cirrhosis, transcriptomic studies of liver biopsies from NAFLD patients have already offered a number of promising biomarkers [74].

In a study of healthy liver tissue, MacParland et al. described 20 discrete cell populations of hepatocytes, endothelial cells, cholangiocytes, hepatic stellate cells, B cells, conventional and non-conventional T cells, NK-like cells, and distinct intrahepatic monocyte/macrophage populations [75]. They showed with single-cell resolution that the gene expression of human hepatocytes, as well as non-paranchymal cells, reflect their position along the porto-central axis in keeping with functional zonation of the lobule. Another single-cell study of human liver further refined the concept of hepatocyte and endothelial cell co-zonation, to suggest cooperation across cell types around essential liver functions [76].

In the first single-cell-resolved study of human liver cirrhosis, Ramachandran et al. compared five healthy liver tissue patients with five cirrhosis patients. The authors identified TREM2+/CD9+ scar-associated macrophages, ACKR1+/PLVAP+ endothelial cells, and PDGFR $\alpha+$ collagen-producing myofibroblasts specifically associated with cirrhosis and spatially restricted to the fibrotic niche [12]. A later study confirmed that PLVAP (plasmalemma vesicle-associated protein) is expressed by hepatic stellate cells, and its expression suppressed upon liver injury in NASH [77]. The same study identified core hepatic stellate cell genes, whose expression proved highly predictive of advanced fibrosis in NASH patients. This highlights the importance of biomarkers that focus on non-parenchymal liver cells, as they are the main actors in the fibrogenic response to liver injury. Similarly, a number of recent single-cell studies of murine NASH models have shed light on hepatic macrophage dynamics and the inflammatory response in NASH livers where macrophages gradually populate the hepatic niche replacing Kupffer cells upon NASH progression, and some assume the scar-associated TREM2+ phenotype described above [78].

\subsection{Cell-Type Resolved Proteomics}

Improvements in mass spectroscopy have made it possible to obtain comprehensive proteome descriptions of individual cell types, stopping short of actual single-cell proteomics [79]. Azimifar et al. purified hepatic cell types from male mice and identified 11,520 proteins to construct a cell-type-resolved atlas of the mammalian liver proteome [80]. They showed that the 100 most abundant proteins comprise over $40 \%$ of the total mass of the proteomes. Many of these proteins were metabolic enzymes, stressing that the liver is a metabolic hub of the body. However, one of the first cell-resolved studies of the human liver proteome revealed large discrepancies between human and murine proteomes [81]. They used three healthy liver transplant donors to perform quantitative proteomics analysis on the major cell lines: Hepatocytes, endothelial cells, Kupfer cells, and hepatic stellate cells. From $>9700$ identified proteins, $53 \%$ ( $>5100)$ were found in all cell types, indicating mutual basal cellular processes.

While actual single-cell proteomics of human livers have not been done yet, recent technological advances has opened up for large-scale proteomics in formalin-fixed, paraffinembedded liver biopsy tissue, with great promise for further understanding of hepatic cells' functional contributions to liver biology [82].

\section{Conclusions}

Current diagnostic tools in NAFLD are of limited use for patients with severe obesity due to lack of technical applicability, moderate diagnostic accuracies for advanced fibrosis, and absence of validated biomarkers for other important indications such as diagnosis of 
NASH, prognostication, monitoring, and efficacy-of-intervention. Fortunately, technological advances progressively allow for large-scale, high-throughput omics analyses. As a consequence, genomics, transcriptomics, and proteomics will, in the coming years, move from basic and translational science into biomarker development and validation.

Author Contributions: Conceptualization, C.W.W. and M.T.; writing—original draft preparation, C.W.W.; writing—review and editing, M.T., K.R., and M.M.L.; visualization, C.W.W. and K.R. All authors have read and agreed to the published version of the manuscript.

Funding: This work was supported by the Danish National Research Foundation (grant DNRF141) to Center for Functional Genomics and Tissue Plasticity (ATLAS). MT is funded by grants from the European Union's Horizon 2020 research and innovation program for the GALAXY project (grant number 668031), the LiverScreen project (grant number 847989), and the MicrobPredict project (grant number 825694); and from the Novo Nordisk Foundation for the MicrobLiver project (grant number NNF15OC0016692) and the DECIDE project (grant number NNF20OC0059393).

Data Availability Statement: No new data were created or analyzed in this study. Data sharing is not applicable to this article.

Conflicts of Interest: M.T. has received author's fee from Echosens.

\begin{abstract}
Abbreviations
2D-SWE, 2-dimensional shear-wave elastography; AUROC, area under the receiver operating characteristics curve; BMI, body mass index; GCKR, glucokinase-regulator; GWAS, genome wide association study; HSD17B13, hydroxysteroid 17-beta dehydrogenase; MRE, magnetic resonance elastography; MRI, magnetic resonance imaging; NAFLD, non-alcoholic fatty liver disease; NASH, non-alcoholic steatohepatitis; PDFF, proton density fat fraction; PNPLA3, patatin-like phospholipase domaincontaining protein 3; pSWE, point shear-wave elastography; SNP, single nucleotide polymorphisms; TE, transient elastography; TM6SF2, transmembrane 6 superfamily member 2.
\end{abstract}

\title{
References
}

1. Swinburn, B.A.; Kraak, V.I.; Allender, S.; Atkins, V.J.; Baker, P.I.; Bogard, J.R.; Brinsden, H.; Calvillo, A.; De Schutter, O.; Devarajan, R.; et al. The Global Syndemic of Obesity, Undernutrition, and Climate Change: The Lancet Commission report. Lancet 2019, 393, 791-846. [CrossRef]

2. Ward, Z.J.; Bleich, S.N.; Cradock, A.L.; Barrett, J.L.; Giles, C.M.; Flax, C.; Long, M.W.; Gortmaker, S.L.; Projected, U.S. State-Level Prevalence of Adult Obesity and Severe Obesity. N. Engl. J. Med. 2019, 381, 2440-2450. [CrossRef]

3. Younossi, Z.M.; Golabi, P.; de Avila, L.; Paik, J.M.; Srishord, M.; Fukui, N.; Qiu, Y.; Burns, L.; Afendy, A.; Nader, F. The global epidemiology of NAFLD and NASH in patients with type 2 diabetes: A systematic review and meta-analysis. J. Hepat. 2019, 71, 793-801. [CrossRef]

4. Ong, J.P.; Elariny, H.; Collantes, R.; Younoszai, A.; Chandhoke, V.; Reines, H.D.; Goodman, Z.; Younossi, Z.M. Predictors of nonalcoholic steatohepatitis and advanced fibrosis in morbidly obese patients. Obes. Surg. 2005, 15, 310-315. [CrossRef]

5. Gholam, P.M.; Flancbaum, L.; Machan, J.T.; Charney, D.A.; Kotler, D.P. Nonalcoholic fatty liver disease in severely obese subjects. Am. J. Gastroenter. 2007, 102, 399-408. [CrossRef] [PubMed]

6. Kleiner, D.E.; Brunt, E.M.; Van Natta, M.; Behling, C.; Contos, M.J.; Cummings, O.W.; Ferrell, L.D.; Liu, Y.C.; Torbenson, M.S.; Unalp-Arida, A.; et al. Design and validation of a histological scoring system for nonalcoholic fatty liver disease. Hepatology 2005, 41, 1313-1321. [CrossRef]

7. Schwabe, R.F.; Luedde, T. Apoptosis and necroptosis in the liver: A matter of life and death. Nat. Rev. Gastroenterol. Hepatol. 2018, 15, 738-752. [CrossRef] [PubMed]

8. Singh, S.; Allen, A.M.; Wang, Z.; Prokop, L.J.; Murad, M.H.; Loomba, R. Fibrosis Progression in Nonalcoholic Fatty Liver versus Nonalcoholic Steatohepatitis: A Systematic Review and Meta-analysis of Paired-Biopsy Studies. Clin. Gastroenterol. Hepatol. 2015, 13, 643-654. [CrossRef] [PubMed]

9. Loomba, R.; Schork, N.; Chen, C.H.; Bettencourt, R.; Bhatt, A.; Ang, B.; Nguyen, P.; Hernandez, C.; Richards, L.; Salotti, J.; et al. Heritability of Hepatic Fibrosis and Steatosis Based on a Prospective Twin Study. Gastroenterology 2015, 149, 1784-1793. [CrossRef]

10. Stender, S.; Kozlitina, J.; Nordestgaard, B.G.; Tybjaerg-Hansen, A.; Hobbs, H.H.; Cohen, J.C. Adiposity amplifies the genetic risk of fatty liver disease conferred by multiple loci. Nat. Genet. 2017, 49, 842-847. [CrossRef]

11. Leung, C.; Rivera, L.; Furness, J.B.; Angus, P.W. The role of the gut microbiota in NAFLD. Nat. Rev. Gastroenterol. Hepatol. 2016, 13, 412-425. [CrossRef] 
12. Ramachandran, P.; Dobie, R.; Wilson-Kanamori, J.R.; Dora, E.F.; Henderson, B.E.P.; Luu, N.T.; Portman, J.R.; Matchett, K.P.; Brice, M.; Marwick, J.A.; et al. Resolving the fibrotic niche of human liver cirrhosis at single-cell level. Nature 2019, 575, 512-518. [CrossRef]

13. Ekstedt, M.; Hagstrom, H.; Nasr, P.; Fredrikson, M.; Stal, P.; Kechagias, S.; Hultcrantz, R. Fibrosis stage is the strongest predictor for disease-specific mortality in NAFLD after up to 33 years of follow-up. Hepatology 2015, 61, 1547-1554. [CrossRef]

14. Blond, E.; Disse, E.; Cuerq, C.; Drai, J.; Valette, P.J.; Laville, M.; Thivolet, C.; Simon, C.; Caussy, C. EASL-EASD-EASO clinical practice guidelines for the management of non-alcoholic fatty liver disease in severely obese people: Do they lead to over-referral? Diabetologia 2017. [CrossRef] [PubMed]

15. Patel, P.; Hossain, F.; Horsfall, L.U.; Banh, X.; Hayward, K.L.; Williams, S.; Johnson, T.; Bernard, A.; Brown, N.N.; Lampe, G.; et al. A Pragmatic Approach Identifies a High Rate of Nonalcoholic Fatty Liver Disease With Advanced Fibrosis in Diabetes Clinics and At-Risk Populations in Primary Care. Hepatol. Commun. 2018, 2, 897-909. [CrossRef] [PubMed]

16. Loomba, R.; Sirlin, C.B.; Ang, B.; Bettencourt, R.; Jain, R.; Salotti, J.; Soaft, L.; Hooker, J.; Kono, Y.; Bhatt, A.; et al. Ezetimibe for the treatment of nonalcoholic steatohepatitis: Assessment by novel magnetic resonance imaging and magnetic resonance elastography in a randomized trial (MOZART trial). Hepatology 2015, 61, 1239-1250. [CrossRef] [PubMed]

17. Sanyal, A.J.; Friedman, S.L.; McCullough, A.J.; Dimick-Santos, L. Challenges and opportunities in drug and biomarker development for nonalcoholic steatohepatitis: Findings and recommendations from an American Association for the Study of Liver Diseases-U.S. Food and Drug Administration Joint Workshop. Hepatology 2015, 61, 1392-1405. [CrossRef] [PubMed]

18. Hsu, C.; Caussy, C.; Imajo, K.; Chen, J.; Singh, S.; Kaulback, K.; Le, M.D.; Hooker, J.; Tu, X.; Bettencourt, R.; et al. Magnetic Resonance vs Transient Elastography Analysis of Patients With Non-alcoholic Fatty Liver Disease: A Systematic Review and Pooled Analysis of Individual Participants. Clin. Gastroenterol. Hepatol. 2018. [CrossRef]

19. Castera, L.; Friedrich-Rust, M.; Loomba, R. Noninvasive Assessment of Liver Disease in Patients With Nonalcoholic Fatty Liver Disease. Gastroenterology 2019, 156, 1264-1281. [CrossRef] [PubMed]

20. Chen, J.; Yin, M.; Talwalkar, J.A.; Oudry, J.; Glaser, K.J.; Smyrk, T.C.; Miette, V.; Sandrin, L.; Ehman, R.L. Diagnostic Performance of MR Elastography and Vibration-controlled Transient Elastography in the Detection of Hepatic Fibrosis in Patients with Severe to Morbid Obesity. Radiology 2017, 283, 418-428. [CrossRef] [PubMed]

21. Imajo, K.; Kessoku, T.; Honda, Y.; Tomeno, W.; Ogawa, Y.; Mawatari, H.; Fujita, K.; Yoneda, M.; Taguri, M.; Hyogo, H.; et al. Magnetic Resonance Imaging More Accurately Classifies Steatosis and Fibrosis in Patients With Nonalcoholic Fatty Liver Disease Than Transient Elastography. Gastroenterology 2016, 150, 626-637. [CrossRef]

22. Middleton, M.S.; Heba, E.R.; Hooker, C.A.; Bashir, M.R.; Fowler, K.J.; Sandrasegaran, K.; Brunt, E.M.; Kleiner, D.E.; Doo, E.; Van Natta, M.L.; et al. Agreement Between Magnetic Resonance Imaging Proton Density Fat Fraction Measurements and Pathologist-Assigned Steatosis Grades of Liver Biopsies From Adults With Nonalcoholic Steatohepatitis. Gastroenterology 2017, 153, 753-761. [CrossRef]

23. Ooi, G.J.; Earnest, A.; Kemp, W.W.; Burton, P.R.; Laurie, C.; Majeed, A.; Johnson, N.; McLean, C.; Roberts, S.K.; Brown, W.A. Evaluating feasibility and accuracy of non-invasive tests for nonalcoholic fatty liver disease in severe and morbid obesity. Int. J. Obes. 2018, 42, 1900-1911. [CrossRef]

24. Zheng, J.; Guo, H.; Zeng, J.; Huang, Z.; Zheng, B.; Ren, J.; Xu, E.; Li, K.; Zheng, R. Two-dimensional Shear-Wave Elastography and Conventional US: The Optimal Evaluation of Liver Fibrosis and Cirrhosis. Radiology 2015, 275, 290-300. [CrossRef] [PubMed]

25. Hernaez, R.; Lazo, M.; Bonekamp, S.; Kamel, I.; Brancati, F.L.; Guallar, E.; Clark, J.M. Diagnostic accuracy and reliability of ultrasonography for the detection of fatty liver: A meta-analysis. Hepatology 2011, 54, 1082-1090. [CrossRef] [PubMed]

26. Mottin, C.C.; Moretto, M.; Padoin, A.V.; Swarowsky, A.M.; Toneto, M.G.; Glock, L.; Repetto, G. The role of ultrasound in the diagnosis of hepatic steatosis in morbidly obese patients. Obes. Surg. 2004, 14, 635-637. [CrossRef] [PubMed]

27. De Moura Almeida, A.; Cotrim, H.P.; Barbosa, D.B.; de Athayde, L.G.; Santos, A.S.; Bitencourt, A.G.; de Freitas, L.A.; Rios, A.; Alves, E. Fatty liver disease in severe obese patients: Diagnostic value of abdominal ultrasound. World J. Gastroenter. 2008, 14, 1415-1418. [CrossRef]

28. Dietrich, C.F.; Bamber, J.; Berzigotti, A.; Bota, S.; Cantisani, V.; Castera, L.; Cosgrove, D.; Ferraioli, G.; Friedrich-Rust, M.; Gilja, O.H.; et al. EFSUMB Guidelines and Recommendations on the Clinical Use of Liver Ultrasound Elastography, Update 2017 (Long Version). Eur. J. Ultrasound 2017, 38, e16-e47. [CrossRef]

29. Cassinotto, C.; Boursier, J.; De Ledinghen, V.; Lebigot, J.; Lapuyade, B.; Cales, P.; Hiriart, J.B.; Michalak, S.; Le Bail, B.; Cartier, V.; et al. Liver stiffness in nonalcoholic fatty liver disease: A comparison of Supersonic Shear Imaging, FibroScan and ARFI with liver biopsy. Hepatology 2016, 63, 1817-1827. [CrossRef]

30. Wong, V.W.-S.; Irles, M.; Wong, G.L.-H.; Shili, S.; Chan, A.W.-H.; Merrouche, W.; Shu, S.S.-T.; Foucher, J.; Le Bail, B.; Chan, W.K.; et al. Unified interpretation of liver stiffness measurement by M and XL probes in non-alcoholic fatty liver disease. Gut 2019, 68, 2057-2064. [CrossRef] [PubMed]

31. Eddowes, P.J.; Sasso, M.; Allison, M.; Tsochatzis, E.; Anstee, Q.M.; Sheridan, D.; Guha, I.N.; Cobbold, J.F.; Deeks, J.J.; Paradis, V.; et al. Accuracy of FibroScan Controlled Attenuation Parameter and Liver Stiffness Measurement in Assessing Steatosis and Fibrosis in Patients With Nonalcoholic Fatty Liver Disease. Gastroenterology 2019, 156, 1717-1730. [CrossRef]

32. Papatheodoridi, M.; Hiriart, J.B.; Lupsor-Platon, M.; Bronte, F.; Boursier, J.; Elshaarawy, O.; Marra, F.; Thiele, M.; Markakis, G.; Payance, A.; et al. Refining the Baveno VI elastography criteria for the definition of compensated advanced chronic liver disease. J. Hepatol. 2020. In press. [CrossRef] [PubMed] 
33. Petroff, D.; Blank, V.; Newsome, P.N.; Shalimar; Voican, C.S.; Thiele, M.; Lédinghen, V.D.; Baumeler, S.; Chan, W.K.; Perlemuter, G.; et al. Controlled attenuation parameter including the XL probe to assess steatosis: An individual patient data meta-analysis. Lancet Gastroenter. Hepat. 2021. In press. [CrossRef]

34. Vali, Y.; Lee, J.; Boursier, J.; Spijker, R.; Löffler, J.; Verheij, J.; Brosnan, M.J.; Böcskei, Z.; Anstee, Q.M.; Bossuyt, P.M.; et al. Enhanced liver fibrosis test for the non-invasive diagnosis of fibrosis in patients with NAFLD: A systematic review and meta-analysis. $J$. Hepatol. 2020, 73, 252-262. [CrossRef]

35. Guillaume, M.; Moal, V.; Delabaudiere, C.; Zuberbuhler, F.; Robic, M.A.; Lannes, A.; Metivier, S.; Oberti, F.; Gourdy, P.; FouchardHubert, I.; et al. Direct comparison of the specialised blood fibrosis tests FibroMeter(V2G) and Enhanced Liver Fibrosis score in patients with non-alcoholic fatty liver disease from tertiary care centres. Aliment. Pharm. 2019, 50, 1214-1222. [CrossRef]

36. Thiele, M.; Madsen, B.S.; Hansen, J.F.; Detlefsen, S.; Antonsen, S.; Krag, A. Accuracy of the Enhanced Liver Fibrosis Test vs Fibrotest, Elastography and Indirect Markers in Detection of Advanced Fibrosis in Patients with Alcoholic Liver Disease. Gastroenterology 2018, 154, 1369-1379. [CrossRef]

37. Karlas, T.; Dietrich, A.; Peter, V.; Wittekind, C.; Lichtinghagen, R.; Garnov, N.; Linder, N.; Schaudinn, A.; Busse, H.; Prettin, C.; et al. Evaluation of Transient Elastography, Acoustic Radiation Force Impulse Imaging (ARFI), and Enhanced Liver Function (ELF) Score for Detection of Fibrosis in Morbidly Obese Patients. PLoS ONE 2015, 10, e0141649. [CrossRef]

38. López, I.C.; Aroca, F.G.; Bernal, M.D.F.; Mompeán, J.A.L.; Bernal, Á.B.; Martínez, A.M.H.; Barba, E.M.; Velasco, J.A.N.; Paricio, P.P. Utility of the ELF Test for Detecting Steatohepatitis in Morbid Obese Patients with Suspicion of Nonalcoholic Fatty Liver Disease. Obes. Surg. 2017, 27, 2347-2353. [CrossRef]

39. Boursier, J.; Vergniol, J.; Guillet, A.; Hiriart, J.-B.; Lannes, A.; Le Bail, B.; Michalak, S.; Chermak, F.; Bertrais, S.; Foucher, J.; et al. Diagnostic accuracy and prognostic significance of blood fibrosis tests and liver stiffness measurement by FibroScan in nonalcoholic fatty liver disease. J. Hepatol. 2016, 65, 570-578. [CrossRef] [PubMed]

40. Daniels, S.J.; Leeming, D.J.; Eslam, M.; Hashem, A.M.; Nielsen, M.J.; Krag, A.; Karsdal, M.A.; Grove, J.I.; Neil Guha, I.; Kawaguchi, T;; et al. ADAPT: An Algorithm Incorporating PRO-C3 Accurately Identifies Patients With NAFLD and Advanced Fibrosis. Hepatology 2019, 69, 1075-1086. [CrossRef] [PubMed]

41. Srivastava, A.; Gailer, R.; Tanwar, S.; Trembling, P.; Parkes, J.; Rodger, A.; Suri, D.; Thorburn, D.; Sennett, K.; Morgan, S.; et al. Prospective evaluation of a primary care referral pathway for patients with non-alcoholic fatty liver disease. J. Hepatol. 2019, 71, 371-378. [CrossRef]

42. Karsdal, M.A.; Henriksen, K.; Nielsen, M.J.; Byrjalsen, I.; Leeming, D.J.; Gardner, S.; Goodman, Z.; Patel, K.; Krag, A.; Christiansen, C.; et al. Fibrogenesis assessed by serological type III collagen formation identifies patients with progressive liver fibrosis and responders to a potential antifibrotic therapy. Am. J. Physiol. Gastrointest. Liver Physiol. 2016, 311, G1009-G1017. [CrossRef] [PubMed]

43. Newsome, P.N.; Sasso, M.; Deeks, J.J.; Paredes, A.; Boursier, J.; Chan, W.K.; Yilmaz, Y.; Czernichow, S.; Zheng, M.H.; Wong, V.W.; et al. FibroScan-AST (FAST) score for the non-invasive identification of patients with non-alcoholic steatohepatitis with significant activity and fibrosis: A prospective derivation and global validation study. Lancet Gastroenterol Hepatol 2020, 5, 362-373. [CrossRef]

44. Courcoulas, A.P.; Christian, N.J.; Belle, S.H.; Berk, P.D.; Flum, D.R.; Garcia, L.; Horlick, M.; Kalarchian, M.A.; King, W.C.; Mitchell, J.E.; et al. Weight change and health outcomes at 3 years after bariatric surgery among individuals with severe obesity. JAMA 2013, 310, 2416-2425. [CrossRef] [PubMed]

45. Yamada, R.; Okada, D.; Wang, J.; Basak, T.; Koyama, S. Interpretation of omics data analyses. J. Hum. Genet. 2020. [CrossRef]

46. Anstee, Q.M.; Darlay, R.; Cockell, S.; Meroni, M.; Govaere, O.; Tiniakos, D.; Burt, A.D.; Bedossa, P.; Palmer, J.; Liu, Y.L.; et al. Genome-wide association study of non-alcoholic fatty liver and steatohepatitis in a histologically-characterised cohort. J. Hepat. 2020, 73, 505-515. [CrossRef]

47. Mardinoglu, A.; Uhlen, M. Liver: Phenotypic and genetic variance: A systems approach to the liver. Nat. Rev. Gastroenterol. Hepatol. 2016, 13, 439-440. [CrossRef] [PubMed]

48. Umans, B.D.; Battle, A.; Gilad, Y. Where Are the Disease-Associated eQTLs? Trends Genet. 2020. In press. [CrossRef]

49. Chalasani, N.; Guo, X.; Loomba, R.; Goodarzi, M.O.; Haritunians, T.; Kwon, S.; Cui, J.; Taylor, K.D.; Wilson, L.; Cummings, O.W.; et al. Genome-wide association study identifies variants associated with histologic features of nonalcoholic Fatty liver disease. Gastroenterology 2010, 139, 1567-1576. [CrossRef]

50. Speliotes, E.K.; Yerges-Armstrong, L.M.; Wu, J.; Hernaez, R.; Kim, L.J.; Palmer, C.D.; Gudnason, V.; Eiriksdottir, G.; Garcia, M.E.; Launer, L.J.; et al. Genome-wide association analysis identifies variants associated with nonalcoholic fatty liver disease that have distinct effects on metabolic traits. Plos Genet. 2011, 7, e1001324. [CrossRef]

51. Walker, R.W.; Belbin, G.M.; Sorokin, E.P.; Van Vleck, T.; Wojcik, G.L.; Moscati, A.; Gignoux, C.R.; Cho, J.; Abul-Husn, N.S.; Nadkarni, G.; et al. A common variant in PNPLA3 is associated with age at diagnosis of NAFLD in patients from a multi-ethnic biobank. J. Hepatol. 2020, 72, 1070-1081. [CrossRef]

52. Teo, K.; Abeysekera, K.W.M.; Adams, L.; Aigner, E.; Anstee, Q.M.; Banales, J.M.; Banerjee, R.; Basu, P.; Berg, T.; Bhatnagar, P.; et al. rs641738C > T near MBOAT7 is associated with liver fat, ALT and fibrosis in NAFLD: A meta-analysis. J. Hepatol. 2021, 74, 20-30. [CrossRef] 
53. Abul-Husn, N.S.; Cheng, X.; Li, A.H.; Xin, Y.; Schurmann, C.; Stevis, P.; Liu, Y.; Kozlitina, J.; Stender, S.; Wood, G.C.; et al. A Protein-Truncating HSD17B13 Variant and Protection from Chronic Liver Disease. N. Engl. J. Med. 2018, 378, $1096-1106$. [CrossRef]

54. DiStefano, J.K.; Kingsley, C.; Craig Wood, G.; Chu, X.; Argyropoulos, G.; Still, C.D.; Doné, S.C.; Legendre, C.; Tembe, W.; Gerhard, G.S. Genome-wide analysis of hepatic lipid content in extreme obesity. Acta Diabet. 2015, 52, 373-382. [CrossRef]

55. Gorden, A.; Yang, R.; Yerges-Armstrong, L.M.; Ryan, K.A.; Speliotes, E.; Borecki, I.B.; Harris, T.B.; Chu, X.; Wood, G.C.; Still, C.D.; et al. Genetic variation at NCAN locus is associated with inflammation and fibrosis in non-alcoholic fatty liver disease in morbid obesity. Hum. Hered. 2013, 75, 34-43. [CrossRef] [PubMed]

56. Gellert-Kristensen, H.; Richardson, T.G.; Davey Smith, G.; Nordestgaard, B.G.; Tybjærg-Hansen, A.; Stender, S. Combined Effect of PNPLA3, TM6SF2, and HSD17B13 Variants on Risk of Cirrhosis and Hepatocellular Carcinoma in the General Population. Hepatology 2020. In press. [CrossRef] [PubMed]

57. Mato, J.M.; Martínez-Chantar, M.L.; Lu, S.C. Systems biology for hepatologists. Hepatology 2014, 60, 736-743. [CrossRef]

58. Moylan, C.A.; Pang, H.; Dellinger, A.; Suzuki, A.; Garrett, M.E.; Guy, C.D.; Murphy, S.K.; Ashley-Koch, A.E.; Choi, S.S.; Michelotti, G.A.; et al. Hepatic gene expression profiles differentiate presymptomatic patients with mild versus severe nonalcoholic fatty liver disease. Hepatology 2014, 59, 471-482. [CrossRef]

59. Younossi, Z.M.; Gorreta, F.; Ong, J.P.; Schlauch, K.; Del Giacco, L.; Elariny, H.; Van Meter, A.; Younoszai, A.; Goodman, Z.; Baranova, A.; et al. Hepatic gene expression in patients with obesity-related non-alcoholic steatohepatitis. Liver Int. 2005, 25, 760-771. [CrossRef] [PubMed]

60. Sreekumar, R.; Rosado, B.; Rasmussen, D.; Charlton, M. Hepatic gene expression in histologically progressive nonalcoholic steatohepatitis. Hepatology 2003, 38, 244-251. [CrossRef] [PubMed]

61. Govaere, O.; Cockell, S.; Tiniakos, D.; Queen, R.; Younes, R.; Vacca, M.; Alexander, L.; Ravaioli, F.; Palmer, J.; Petta, S.; et al. Transcriptomic profiling across the nonalcoholic fatty liver disease spectrum reveals gene signatures for steatohepatitis and fibrosis. Sci. Transl. Med. 2020, 12. [CrossRef]

62. Vandel, J.; Dubois-Chevalier, J.; Gheeraert, C.; Derudas, B.; Raverdy, V.; Thuillier, D.; Van Gaal, L.; Francque, S.; Pattou, F.; Staels, B.; et al. Hepatic molecular signatures highlight the sexual dimorphism of Non-Alcoholic SteatoHepatitis (NASH). Hepatology 2020. [CrossRef]

63. Baselli, G.A.; Dongiovanni, P.; Rametta, R.; Meroni, M.; Pelusi, S.; Maggioni, M.; Badiali, S.; Pingitore, P.; Maurotti, S.; Montalcini, T.; et al. Liver transcriptomics highlights interleukin-32 as novel NAFLD-related cytokine and candidate biomarker. Gut 2020, 69, 1855-1866. [CrossRef]

64. Aebersold, R.; Mann, M. Mass-spectrometric exploration of proteome structure and function. Nature 2016, 537, 347-355. [CrossRef]

65. Charlton, M.; Viker, K.; Krishnan, A.; Sanderson, S.; Veldt, B.; Kaalsbeek, A.J.; Kendrick, M.; Thompson, G.; Que, F.; Swain, J.; et al. Differential expression of lumican and fatty acid binding protein-1: New insights into the histologic spectrum of nonalcoholic fatty liver disease. Hepatology 2009, 49, 1375-1384. [CrossRef]

66. Bell, L.N.; Theodorakis, J.L.; Vuppalanchi, R.; Saxena, R.; Bemis, K.G.; Wang, M.; Chalasani, N. Serum proteomics and biomarker discovery across the spectrum of nonalcoholic fatty liver disease. Hepatology 2010, 51, 111-120. [CrossRef]

67. Niu, L.; Geyer, P.E.; Wewer Albrechtsen, N.J.; Gluud, L.L.; Santos, A.; Doll, S.; Treit, P.V.; Holst, J.J.; Knop, F.K.; Vilsbøll, T.; et al. Plasma proteome profiling discovers novel proteins associated with non-alcoholic fatty liver disease. Mol. Syst. Biol. 2019, 15, e8793. [CrossRef]

68. Caussy, C.; Ajmera, V.H.; Puri, P.; Hsu, C.L.-S.; Bassirian, S.; Mgdsyan, M.; Singh, S.; Faulkner, C.; Valasek, M.A.; Rizo, E.; et al. Serum metabolites detect the presence of advanced fibrosis in derivation and validation cohorts of patients with non-alcoholic fatty liver disease. Gut 2018. [CrossRef] [PubMed]

69. Puri, P.; Daita, K.; Joyce, A.; Mirshahi, F.; Santhekadur, P.K.; Cazanave, S.; Luketic, V.A.; Siddiqui, M.S.; Boyett, S.; Min, H.-K.; et al The presence and severity of nonalcoholic steatohepatitis is associated with specific changes in circulating bile acids. Hepatology 2018, 67, 534-548. [CrossRef] [PubMed]

70. Moolla, A.; de Boer, J.; Pavlov, D.; Amin, A.; Taylor, A.; Gilligan, L.; Hughes, B.; Ryan, J.; Barnes, E.; Hassan-Smith, Z.; et al Accurate non-invasive diagnosis and staging of non-alcoholic fatty liver disease using the urinary steroid metabolome. Aliment. Pharmacol. Ther. 2020, 51, 1188-1197. [CrossRef] [PubMed]

71. Mardinoglu, A.; Wu, H.; Bjornson, E.; Zhang, C.; Hakkarainen, A.; Räsänen, S.M.; Lee, S.; Mancina, R.M.; Bergentall, M.; Pietiläinen, K.H.; et al. An Integrated Understanding of the Rapid Metabolic Benefits of a Carbohydrate-Restricted Diet on Hepatic Steatosis in Humans. Cell Metab. 2018, 27, 559-571. [CrossRef] [PubMed]

72. Eberwine, J.; Sul, J.-Y.; Bartfai, T.; Kim, J. The promise of single-cell sequencing. Nat. Methods 2014, 11, 25-27. [CrossRef] [PubMed]

73. Xiong, X.; Kuang, H.; Liu, T.; Lin, J.D. A Single-Cell Perspective of the Mammalian Liver in Health and Disease. Hepatology 2020, 71, 1467-1473. [CrossRef] [PubMed]

74. Ramachandran, P.; Matchett, K.P.; Dobie, R.; Wilson-Kanamori, J.R.; Henderson, N.C. Single-cell technologies in hepatology: New insights into liver biology and disease pathogenesis. Nat. Rev. Gastroenterol. Hepatol. 2020, 17, 457-472. [CrossRef] [PubMed]

75. MacParland, S.A.; Liu, J.C.; Ma, X.Z.; Innes, B.T.; Bartczak, A.M.; Gage, B.K.; Manuel, J.; Khuu, N.; Echeverri, J.; Linares, I.; et al. Single cell RNA sequencing of human liver reveals distinct intrahepatic macrophage populations. Nat. Commun. 2018, 9, 4383. [CrossRef] 
76. Aizarani, N.; Saviano, A.; Mailly, L.; Durand, S.; Herman, J.S.; Pessaux, P.; Baumert, T.F.; Grün, D. A human liver cell atlas reveals heterogeneity and epithelial progenitors. Nature 2019, 572, 199-204. [CrossRef]

77. Terkelsen, M.K.; Bendixen, S.M.; Hansen, D.; Scott, E.A.H.; Moeller, A.F.; Nielsen, R.; Mandrup, S.; Schlosser, A.; Andersen, T.L.; Sorensen, G.L.; et al. Transcriptional dynamics of hepatic sinusoid-associated cells after liver injury. Hepatology 2020, 72, $2119-2133$. [CrossRef]

78. Krenkel, O.; Hundertmark, J.; Abdallah, A.T.; Kohlhepp, M.; Puengel, T.; Roth, T.; Branco, D.P.P.; Mossanen, J.C.; Luedde, T.; Trautwein, C.; et al. Myeloid cells in liver and bone marrow acquire a functionally distinct inflammatory phenotype during obesity-related steatohepatitis. Gut 2020, 69, 551-563. [CrossRef]

79. Mann, M.; Kulak, N.A.; Nagaraj, N.; Cox, J. The Coming Age of Complete, Accurate, and Ubiquitous Proteomes. Mol. Cell 2013, 49, 583-590. [CrossRef]

80. Azimifar, S.B.; Nagaraj, N.; Cox, J.; Mann, M. Cell-type-resolved quantitative proteomics of murine liver. Cell Metab. 2014, 20, 1076-1087. [CrossRef]

81. Ölander, M.; Wiśniewski, J.R.; Artursson, P. Cell-type-resolved proteomic analysis of the human liver. Liver Int. 2020, 40, 1770-1780. [CrossRef] [PubMed]

82. Coscia, F.; Doll, S.; Bech, J.M.; Schweizer, L.; Mund, A.; Lengyel, E.; Lindebjerg, J.; Madsen, G.I.; Moreira, J.M.; Mann, M. A streamlined mass spectrometry-based proteomics workflow for large-scale FFPE tissue analysis. J. Pathol. 2020, 251, 100-112. [CrossRef] [PubMed] 